\title{
Reflections on the early history of Perception \& Psychophysics
}

\author{
Charles W. ERIKSEN \\ Professor Emeritus, University of Illinois, Urbana-Champaign \\ and Founding Editor of Perception \& Psychophysics
}

Perception \& Psychophysics was founded in 1966 by Clifford T. Morgan. After World War II (WWII) Cliff had received a faculty appointment at the Johns Hopkins University to build a psychology department. He quickly put together an outstanding faculty, nearly all of whom were or soon became prominent in their fields. But Cliff was a complex person who was always searching for the life that would satisfy him. He resigned from Hopkins in 1954 and moved to some acreage on the Choptank River on the Maryland eastern shore. There he spent his time on the Introduction to Psychology that he had written in collaboration with some of the members of the Johns Hopkins psychology department. (He had already authored the highly successful textbook Physiological Psychology as well as several other books, and the royalties from these gave him independence from a university appointment.)

At the time that Cliff founded Perception \& Psychophysics $(P \& P)$, the publication environment for experimental psychologists was quite bleak. There were Carl Murchison's nonrefereed journals - for example, the Journal of Psychology and the Journal of General Psychology, where the main criterion for publication was whether the author could pay the per-page charge for publication. Then there was the Journal of Experimental Psychology and the American Journal of Psychology, both refereed journals. The American Journal was owned by Karl Dallenbach. On the cover, he was named as the editor, and a small group of experimental and measurement psychologists were also named as collaborators. These collaborators were all prominent pre-WWII psychologists. At this time, Dallenbach was quite advanced in age. If one submitted a manuscript to the journal, one might find that Dallenbach had accepted it but had largely rewritten it and missed the main points. If one felt that to be the case, one could send back the original version of the paper, and that would appear in the journal.

The Journal of Experimental Psychology was the premier journal for experimental psychologists, but here the definition of experimental psychology was rather narrow. Much of what is now cognitive psychology would not have met the criterion of "experimental" for the journal. Data had to be analyzed in terms of $t$ tests or ANOVAs, so if an author's main data analysis was done in terms of correlation coefficients, the author would have to seek another avenue for publication. The American Psychological Association owned the Journal of Experimental Psychology and several other journals, and the number of pages per year was dictated by the APA's budget. Thus, when the number of pages for a given year was reached, accepted articles had to wait until the next budget year for publication. It was not unusual for nearly a year to pass from submission of a manuscript until it appeared in print.

Before WWII, the number of experimental psychologists was quite small. Most of them knew one another, and the research culture was quite different from today's. This is well reflected in some advice that E. R. Hilgard once gave me. Hilgard was chairman of the psychology department at Stanford when I did my graduate work there. I encountered him on a train in 1952, a couple of years after I had received my PhD. During our conversation, I remarked that I had three articles in press. He looked quite concerned and told me that I should be careful and not publish too much; otherwise, I would get the reputation for doing trivial and superficial research. It must be remembered, though, that Hilgard said this at a time when money for research had been quite scarce. It was not until the early 1950s that research grants in the behavioral and social sciences became available from NSF and NIMH.

Although Cliff Morgan himself was no longer active in research, he was acutely aware of the publication bottleneck for experimental psychologists. The number of psychologists had mushroomed after the war. With research grants from NSF and NIMH, laboratories had been established and data were flowing forth. Cliff saw this as an opportunity to do a service to psychology and also as a business opportunity. In 1962, he started the Psychonomic Press in Goleta, California, at about the same time as Larry Erlbaum was starting Academic Press. This was largely a family operation, consisting of Cliff, his wife Jean, his sons Peter and Michael, and his daughter Pat.

C.W. Eriksen, erikbarb@consolidated.net 
Anne Dossett joined the enterprise in 1964. Although the main purpose of the press was to establish quality journals devoted to psychology, the press also engaged in other printing jobs. It even published hardcover textbooks-for example, Robert Beecroft's Classical Conditioning. The first journal, Psychonomic Science, appeared in 1963. It was devoted to short articles in experimental and comparative psychology. $P \& P$ appeared in 1966 . It was a monthly journal, with one volume per year.

Cliff launched $P \& P$ with the assistance of an editorial board consisting of about a half dozen or more prominent experimentalists with specialties in various areas of perception and psychophysics. Cliff was the managing editor, but he did not process submitted manuscripts. Authors submitted their manuscripts to a board member whom they thought would be appropriate. The aim of the journal was to publish quality, well-refereed work, with a minimum of publication delay. There was no maximum number of pages per volume.

Other than being an initial subscriber, my contact with the journal began in 1969 at a meeting of the Society of Experimental Psychologists at Mt. Holyoke. Following the concluding dinner, a group of us adjourned to Cliff's room for good conversation, martinis, and bourbon and branch water. (The psychologists of my generation were a hard liquor group; no white wine for them. I was told by several bartenders that they were happy when psychologists had conventions in their city. And we had some classic drunks, sources of stories and amusement. They could be found staggering around the lobby of the hotel at 1 a.m.) By midnight, the group had dwindled down to Cliff and me. We continued drinking and talking until 6 a.m. Somehow during this period, Cliff persuaded me to become editor of $P \& P$. I had the good sense to postpone the position for a year until I finished a term on an NIMH study section. I was also editor of the American Journal of Psychology at the time. Dallenbach had died and left that journal to the University of Illinois. Lloyd Humphreys was the new editor and I the associate. But at that time I was the editor, since Lloyd was off for a year as an administrator at NSF. I was busy bringing the journal into the 20th century, with the assistance of Sharon Ferguson from the University of Illinois Press. Sharon changed the format of the journal and increased the physical size and front cover, and I changed the editorial structure. I wanted this to be accomplished before Lloyd returned from Washington.

When the year was up, Cliff held me to my commitment, and I found myself editor of $P \& P$ with 6 months still left as editor of the American Journal. $P \& P$ was quite disorganized. There were more than a half dozen independent editors with varying criteria for acceptance of manuscripts, and there was the Psychonomic Press with little or no knowledge of how many manuscripts were in editorial processing. The journal was published monthly, but since there was little knowledge of how many accepted manuscripts to expect, it was quite difficult to plan an issue. Cliff had told me that I would have a free hand with the journal, with the only restriction that I could not fire any of the members of the editorial board. He felt indebted to them for their help in launching the journal. Diplomacy has never been my strong suit, but I began slowly to centralize the journal's editorial functioning.

I began by asking the members of the board to supply me with a monthly report of manuscripts received and referees assigned and to send accepted manuscripts to my office for some redacting before they were sent to the publications office. Several members used this occasion to resign. I don't know whether this additional paperwork was too much for them or they were not really enthusiastic about the job of being editors. One member replied to my request by stating that he would continue to operate as he had been doing. I informed him that he could continue to do so, but that he would then need to explain to authors why their paper never appeared in the journal. His response was to resign. My next step in obtaining editorial control was to require authors to submit their manuscripts to my office. Board members were asked to forward any manuscript submitted directly to them to my office for assignment of an action editor.

The Journal of Experimental Psychology was the highprestige journal for experimental psychologists, and it was my intention to emulate that journal's editorial structure. This consisted of an editor, one associate editor, and a stable of official consulting editors. However, even with a few resignations from the editorial board, I still had seven remaining members. All seven were doing a creditable job as editors. They were conscientious and prompt, and they showed good editorial judgment. Moreover, they represented different areas of expertise. $P \& P$ covered a broad area of research specialties - psychophysics, auditory perception, visual perception, attention - and it included research using human as well as animal subjects. I had my own experience as an author with incompetent and very biased reviews, and I regretted the occasions when the action editor on my manuscript was not expert enough in my research area to detect this on his own. Such expertise would have saved me the trouble of having to educate him. Not only was it desirable to have action editors able to evaluate the adequacy of reviews, they would have to choose appropriate people to review manuscripts.

Since the number of associate editors for a journal is not written in stone, I thought it best to have enough associate editors to represent the different subject areas covered by the journal. But there were financial considerations as well. The journal was operating on a shoestring budget. Although individual and institutional subscriptions were growing, Cliff was still having to finance some of the expenses from his own pocket. There were no honoraria for editors or for editorial assistants. I reasoned that if one had enough associate editors, they would have a workload on the average of only two or three manuscripts a month and would not need editorial assistance. Furthermore, with such a light workload, it would be easier to persuade highly productive and competent people to take on the role of associate editor. Finally, with so few manuscripts per editor, one could expect that the board members' own departments would provide incidentals such as postage. 
So instead of pruning the editorial board put together by Cliff, I decided to add a few people to cover some of the journal's subject areas.

By the end of 1971, my first year as editor, all seven of the original board members were still on board: Norman Anderson, Richard Atkinson, Walter Gogel, Alfred Kristofferson, Herschel Leibowitz, James D. Miller, and Irwin Pollack. During the next year, Anderson and Miller resigned and were replaced in an expanded board by V. R. Carlson, Edward C. Carterette, Robert Fox, and James J. Jenkins. Ed Carterette and Bob Fox continued to serve as associate editors during my entire tenure as editor. Their suggestions and counsel over the years contributed in important ways to the success of the journal.

Much paperwork is involved in editing a journal. I was fortunate to have a secretary, Elsie Osterbur, who was willing to add the role of editorial assistant to her duties around my lab. In this role, she handled the correspondence and record keeping as well as some redacting of manuscripts. Redaction involved checking accepted manuscripts for suitability of tables and figures and assuring that all citations were referenced in the bibliography. She also contributed some cost-saving ideas. By perusing the postal regulations, she discovered that a manuscript could be mailed at the book rate at an appreciable saving.

It was typical in those days for an author to submit a manuscript in triplicate. The three copies were probably dictated by the number of legible carbons that could be produced by typewriters. However, with the rise of copiers (and then computers and printers), the number of copies was not limited. So $P \& P$ instituted a requirement of four copies of a submitted manuscript and later increased this to five. The discovery that these manuscripts could be mailed at book rate made this affordable. With these extra copies, action editors could solicit two reviews at the same time, speeding the review process. Moreover, since the reviewers did not need to return the manuscript, return postage was saved.

In a very real sense, the standards for publication in a journal are set by the outside reviewers. $P \& P$ never had difficulty in obtaining well-qualified people to review manuscripts. Typically, two reviews were solicited, and in cases where there was a problem another outside review would be obtained. The Journal of Experimental Psychology had the custom of listing its frequently used reviewers on the cover as consulting editors, and we soon emulated this practice. We listed the reviewers that the associate editors and I found to give prompt, good-quality reviews and who, as a result, were frequently utilized. Reviewing the work of others not only takes time away from the reviewer's own research time, but requires a critical capacity that not all investigators have, even though their own research may be outstanding.

From the outset, $P \& P$ had no difficulty in attracting quality manuscripts. Even in the beginning, some came from authors at foreign institutions. (In later years, it was not unusual for nearly half of the articles in an issue to be from foreign institutions.) In part this was due to the dearth of publication avenues that existed when the jour- nal was founded. Typically, from 230 to 300 manuscripts a year were submitted. The rejection rate varied from $40 \%$ to $55 \%$. This varied among action editors mainly because of differences in the specialty areas that the editors covered. My rejection rate ran at 55\%, because I handled all incoming manuscripts initially and could quickly weed out inappropriate submissions and what we called "full moon manuscripts" that ought to have come with mental hospital return addresses. Occasionally, the author of a paper, rejected by one of my editors, would appeal to me, but he or she would be informed that I was not a court of appeals. I did not second-guess my associate editors.

When Cliff founded the journal, one of his goals was quick publication. At $P \& P$ we strove for a publication lag of 3 months or less. Editors do not have complete control over the time of the reviewing process. They depend on the promptness of reviewers. If reviews were completed within 30 days, the 3-month lag could be realized. When an article appeared in the journal, the date of submission of the manuscript was noted. Early on, we began the practice of also noting the date that any revision was received. If the author was slow in submitting an acceptable revision, we did not want the journal to be blamed for the delay in publication.

$P \& P$ was never saddled with a yearly page maximum. In later years, the Publications Committee of the Psychonomic Society required an estimate from editors as to the number of pages that would be needed for the coming year, but either the provided estimates were never exceeded or, if they were, were disregarded. Once an accepted manuscript was in the publications office, it was quickly given what further redacting was necessary and set up for printing. Anne Dossett was the production manager, and she ensured that the monthly issues of the journal were on schedule.

In 1976, following discussions with Bob Fox, I introduced a Notes and Comment section in the journal. It seemed to serve a useful function, because it received numerous submissions. I was rigid in adhering to the criteria of true notes or comment, although authors continued to submit short experimental reports for publication in this section of the journal. The Bulletin of the Psychonomic Society was devoted to short experimental reports, and I did not want $P \& P$ to compete with the Bulletin. Any member of the Psychonomic Society could publish in the Bulletin, but those papers were not refereed. Apparently, authors preferred the status of $P \& P$ as a refereed journal. However, if the short experimental report appeared to be a solid contribution, I would offer to sponsor the paper for the Bulletin if the author happened not to be a member of the Society.

For some time, Cliff had been planning to give his journals to the Psychonomic Society. During 1971, ownership of P\&P, Psychonomic Science, and Behavior Research Methods \& Instrumentation was passed to the Society. By then, Cliff had moved to Austin, Texas, and had a position as adjunct professor in the psychology department of the University of Texas. Ann Sanford, managing editor for Psychonomic Society Publications, had her office there, but 
Anne Dossett, production manager, remained in Goleta, California, for a while longer before moving production to Austin. Cliff assumed the role of Director of Publications for the Psychonomic Society, a position that he held until his untimely death from a heart attack in 1976.

Following the acquisition of the journals, the membership of the Psychonomic Society voted to raise dues to provide monetary support for the journals that they now owned and others that were in the process of being created. With the increased financial support, editors were now provided with honoraria and there were funds for my part-time editorial assistant.

As I mentioned, Cliff Morgan died suddenly of a heart attack in early 1976 . By then, the success of $P \& P$, as well as of the other journals that Cliff had launched, was assured. After Cliff's death, I tried on several occasions to resign as editor but was always talked out of it by members of the Publications Committee. I don't know whether this was because of my penny-pinching ways or because they did not want the work of finding another editor. So I quit broaching the subject. I figured that when the Committee wanted another editor they would let me know. As for myself, the role of editor had been well integrated into my other activities. I had been successful in obtaining the services of highly competent people as associate editors, who deserve the major credit for the success of the journal.

In 1993, I retired and became professor emeritus at the University of Illinois at Urbana-Champaign, and this seemed an appropriate time to turn the journal over to younger blood. I was very pleased when the Publications Committee selected Myron Braunstein as the new editor. On the basis of his performance as an associate editor, I had recommended him most highly to the Committee. I could rest assured that the future of $P \& P$ was in very capable hands.

\section{NOTE}

For those interested in more on this topic, see Dewsbury, D. A. (1996). History of the Psychonomic Society II: The journal publishing program. Psychonomic Bulletin \& Review, 3, 322-338. 